\title{
ANALISIS PEMETAAN PENELITIAN MAHASISWA PROGRAM STUDI PENDIDIKAN FISIKA FKIP UNIVERSITAS MATARAM
}

\author{
I Wayan Gunada ${ }^{1}$, Ahmad Harjono ${ }^{2}$ \\ 1) 2) Program Studi Pendidikan Fisika FKIP Universitas Mataram \\ Email: wayan_gunada@yahoo.com
}

\begin{abstract}
Abstrak: Penelitian ini bertujuan untuk mengidentifikasi, menganalisis, dan memetakan hasil - hasil penelitian pendidikan mahasiswa PS. Pendidikan Fisika FKIP Unram. Metode penelitian ini menggunakan penelitian studi kasus (casus study research). Variabel lain yang terlibat dalam penelitian ini adalah subjek penelitian, jenis- jenis penelitian, bidang kajian penelitian, isu-dan isu bidang pendidikan. Subjek penelitian ini adalah hasil penelitian akhir atau skripsi mahasiswa Program Studi Pendidikan Fisika FKIP Unram selama kurun waktu 6 tahun terakhir. Hasil penelitian menunjukan bahwa subjek penelitian yang paling banyak diteliti oleh mahasiswa adalah SMP/MTs, jenis penelitiannya kategori penelitian eksperimen. Sedangkan isu-isu utama penelitian pendidikan yang banyak diteliti oleh mahasiawa adalah model pembelajaran dan metode pembelajaran, sedangkan isu -isu skunder yang paling banyak diteliti adalah hasil belajar dan prestasi belajar.Isu-isu pendidikan yang masih memungkinkan diteliti lebih lanjut adalah keadaan lab, kognitif, life skills, keterampilan berpikir, pendalaman konsep, dan miskonsepsi. Kategori jenis penelitian pengembangan perlu diarahkan ke siswa. Hasil pemetaan ini diharapkan dapat memberikan masukan bagi dosen dosen di lingkungan PS. Pendidikan Fisika dalam mengarahkan dan menentukan judul penelitian yang diajukan oleh mahasiswa. Pemetaan hasil penelitian ini memungkinkan adanya pengembangan jenis penelitian, variabel, desain, isu atau kajian penelitian yang memungkinkan diteliti lebih lanjut oleh mahasiswa.
\end{abstract}

Kata Kunci: Pemetaan penelitian mahasiswa , Pendidikan Fisika

\begin{abstract}
The purpose of this study is to identify, analyze, and map the results of student research in Physics Education Study Program, FKIP Unram. This study used a case study research. The variables involved in this research were the subject of research, type of research, field study research and educational issues. Subjects in the study were the result of the final research thesis on Physics Education Study Program FKIP Unram during the period of 6 years. The results showed that most research subjects is SMP/MTs, the type of research is experimental research category. The main issue of research is a model of learning and teaching methods, the secondary issue most studied is the result of learning outcomes and achievement. Education issues that could be examined further are the state lab, cognitive, life skills, thinking skills, deepening concepts and misconceptions. This type of research should be directed to the development of students. This mapping result is expected to provide input for lecturers in Physics Education Study Program in directing and determining title research to be conducted by the students. This mapping result could contribute to the development of research types, variables, designs, issues or research studies that can be further investigated by the students in Physics Education Study Program, FKIP Unram.
\end{abstract}

Keywords: Maping student research, Physics Education

\section{PENDAHULUAN}

Salah satu lembaga yang memiliki peran dalam menghasilkan SDM yang berkualitas adalah Perguruan Tinggi (PT). Peran yang dilakukan ialah dengan menjaga kualitas proses pembelajaran dan meningkatkan kualitas lulusannya. Program Studi Pendidikan Fisika FKIP Unram, sebagai salah satu progam studi di perguruan tinggi Universitas Mataram, juga mendapatkan kewajiban yang sama untuk berperan dalam menghasilkan lulusan bermutu dan berdaya saing tinggi. Seperti yang dijabarkan dalam misi dan tujuan program studi diantaranya, dapat diandalkan sebagai pencetak guru yang kompeten dalam bidang pendidikan fisika dan mengembangkan penelitian di bidang pendidikan fisika dalam rangka meningkatkan kualitas sesuai kebutuhan masyarakat pengguna [1]. Untuk mencapai tujuan tersebut salah satu sasaran yang ditempuh adalah massa studi sama dengan atau kurang dari 4 tahun. Penyelesaian massa studi diakhiri dengan menempuh dan menyelesikan skripsi.

Skripsi merupakan mata kuliah wajib yang harus ditempuh dan wajib lulus bagi setiap mahasiswa program studi Pendidikan Fisika FKIP Universitas Mataram. Mata kuliah ini menjadi tolak ukur menyelesaikan program jenjang strata satu (S1). Tujuan utama diselenggarakan mata kuliah ini salah satunya untuk memberikan bekal dan wawasan kepada peserta didik mengenai keterampilan melakukan penelitian dalam bidang pendidikan khususnya Pendidikan Fisika. Mahasiswa yang dapat mengajukan mata kuliah ini, jika memenuhi persyaratan diantaranya telah menempuh minimal $80 \%$ kredit kumulatif kelulusan yang ditetapkan oleh program studi dan telah menempuh mata kuliah metodologi penelitian [2]. Persyaratan tersebut telah memberikan gambaran awal kepada mahasiswa mengenai jenis - jenis penelitian, metode penelitian yang digunakan dan berbagai komponen yang harus dipahami sebelum melakukan penelitian [3]. 
Penelitian atau riset berasal dari bahasa Inggris research yang artinya adalah proses pengumpulan informasi dengan tujuan meningkatkan, memodifikasi atau mengembangkan sebuah penyelidikan atau kelompok penyelidikan. Pada dasarnya riset atau penelitian adalah setiap proses yang menghasilkan ilmu pengetahuan. Menurut [4] penelitian adalah investigasi yang sistematis, terkontrol, empiris dan kritis dari suatu preposisi hipotesis mengenai hubungan tertentu antar fenomena. Sedangkan [5] mendefinisikan penelitian merupakan suatu usaha yang sistematis untuk menemukan jawaban ilmiah terhadap suatu masalah (a systematic attempt to provide answer to question). Sistematis artinya mengikuti prosedur atau langkah-langkah tertentu. Jawaban ilmiah adalah rumusan pengetahuan, generaliasi, baik berupa teori, prinsip baik yang bersifat abstrak maupun konkret yang dirumuskan melalui alat primernya yaitu empiris dan analisis. Penelitian itu sendiri bekerja atas dasar asumsi, teknik dan metode.

Kecendrungan dan tren penelitian pendidikan sains khususnya pendidikan fisika selalu mengalami perubahan dari waktu ke waktu. Perubahan yang terjadi mengikuti fenomena perubahan yang terjadi di lapangan. Menurut White (1997) dalam [3] mengungkapkan beberapa topik penelitian cenderung menghilang dan topik-topik tertentu cenderung muncul kembali. Fokus penelitian pendidikan sains di negaranegara maju mengalami perubahan sejalan dengan reformasi pendidikan sains yang sedang dijalankan oleh negara-negara tersebut. Sebagai gambaran, Amerika sudah mengalami tiga gelombang reformasi pendidikan sains, yaitu dalam tahun 1950an, 1980an dan 1990an (de Jong, 2007 dalam [6] ). Pada era tahun 1980an sebagai subjeknya adalah peserta didik khususnya tentang pemahaman konsep, sedangkan pada era 1990 subjek penelitian memusat pada pendekatan konstruktivisme dan kontekstual.

Penelitian pendidikan sains pada tahun tahun terakhir telah menunjukan suatu pergeseran kearah paradigm konstruktivis [7]. Filsafat konstruktivisme adalah filsafat yang mempelajari hakikat pengetahuan dan bagaimana pengetahuan terjadi. [7] mengungkapkan bahwa beberapa metode pembelajaran yang dapat diterapkan dalam pembelajaran fisika diantaranya : inquiry, discovery, eksperimen, demontrasi, permainan, karya wisata, dan lain-lainnya. Seperti yang diungkapkan [3] mengatakan bahwa aspek yang tidak kalah pentingnya dalam penelitian adalah menyesuaikan karakteristik materi pembelajaran dengan jenis metode atau model pembelajaran yang diterapkan di kelas.

Tugas Akhir atau skripsi merupakah mata kuliah keahlian berkarya (MKB) dengan kode mata kuliah 133729 yang wajib ditempuh oleh mahasiswa PS. Pendidikan Fisika FKIP Unram. Bobot kredit mata kuliah skripsi ini adalah empat (4 sks). Dalam buku pedoman penyelenggaraan pendidikan FKIP Unram tahun 2009 dijelaskan bahwa karya ilmiah akhir program yang berbentuk skripsi adalah karya yang ditulis oleh mahasiswa berdasarkan penelitian dan kajian ilmiah berdasarkan disiplin ilmu yang diselenggarakan secara seksama dan dibimbing oleh 2 (dua) orang dosen pembimbing. Penulisan karya ilmiah bertujuan untuk meningkatkan dan mengembangkan daya nalar mahasiswa dalam menerapkan konsep dan teori yang diperoleh selama perkuliahan.

Dengan demikian, skripsi merupakan hasil karya dari mahasiswa serta dapat menjadi salah satu indikator keberhasilan yang diperoleh mahasiswa selama menekuni disiplin ilmunya masing-masing. Seperti yang diungkapkan [8] menyatakan bahwa tuntutan dalam skripsi bagi mahasiswa S1 adalah untuk melaksanakan proses penelitian secara benar sesuai dengan kaidah yang berlaku tanpa ada keharusan menemukan dan mengoreksi teori yang telah ada. Dengan demikian, selama mahasiswa mampu melakukan langkah-langkah dalam kegiatan penelitian secara urut dan benar maka tugas akhir skripsi tersebut sudah memenuhi syarat.

Menghasilkan karya ilmiah di bidang pendidikan fisika yang handal dan dapat dipublikasikan secara nasional dan internasional merupakan salah satu tujuan PS. Pendidikan Fisika. Sehingga pada akhirnya dapat mewujudkan visi Program Studi Pendidikan Fisika yang bermutu dan berdaya saing tinggi seperti yang tertuang dalam borang akreditasi program studi.

Analisis pemetaan penelitian mahasiswa ini, memungkinkan adanya pengembangan jenis penelitian, variabel, desain, isu atau kajian penelitian yang memungkinkan diteliti lebih lanjut oleh mahasiswa. Apabila isu pendidikan yang di teliti oleh mahasiswa semakin banyak, maka mahasiswa diharapkan dapat dengan mudah menentukan tema penelitian, sehingga penyelesaian tugas akhirnya dapat dipercepat. Hal ini secara tidak langsung akan menunjang peningkatan akreditasi Program Studi Pendidikan Fisika, karena salah satu indikatornya yang tertuang dalam borang akreditasi tepatnya pada standar 3 adalah mahasiswa dan kelulusan. Kelulusan yang dimaksud adalah massa studi mahasiswa lebih cepatmenyebutkan atau menghafalkan, tetapi tingkatan yang lebih tinggi, seperti berpikir kritis. Selain itu, apabila proses belajar berlangsung dengan baik, diharapkan motivasi belajar siswa semakin meningkat sehingga terwujudnya hasil belajar yang optimal.

\section{METODE PENELITIAN}

Penelitian ini bertujuan untuk mengidentifikasi, menganalisis, dan memetakan hasil hasil penelitian pendidikan mahasiswa selama kurun waktu 6 tahun terakhir. Desain penelitian in adalah jenis penelitian studi kasus (casus study research). Variabel yang menjadi sasaran dalam penelitian ini adalah teridentifikasinya dan terpetakannya penelitian pendidikan mahasiswa PS. Pendidikan Fisika. 
Penelitian ini dilaksanakan di Program Studi Pendidikan Fisika FKIP Unram yang beralamatkan di Jalan Majapahit No 62 Mataram.

Data yang digunakan dalam menentukan pemetaan penelitian mahasiswa diperoleh dengan melakukan Focus Group Discussion (FGD) dan teknik dokumentasi. Melalui teknik FGD, data dikumpulkan dengan cara berdiskusi secara langsung kepada nara sumber yang berasal dari beberapa mahasiswa. Sedangkan melalui metode dokumentasi dikumpulkan data primer yang diperoleh dari skripsi mahasiwa selama enam tahun terakhir. Metode dokumentasi diperlukan untuk mengungkap sejauh mana indikator yang diinginkan teridentifikasinya bidang penelitian pendidikan fisika

Seluruh data yang terkumpul dianalisis dengan dengan teknik deskriptif, kuantitatif, dan kualitatif dengan langkah - langkah : a) pengumpulan data kasar, b) pemilihan data (data selection), c) data recording dan organisasi data, d) analisis deskriptif kuantitatif e) interpretasi hasil.

\section{HASIL DAN PEMBAHASAN}

Selama kurun waktu enam tahun terakhir (2009 sampai dengan 2014) telah dihasilkan sebanyak 234 judul penelitian mahasiswa. Berdasarkan hasil temuan dan analisis penelitian yang dilakukan oleh peneliti ditemukan sebagai berikut:

\section{Subjek Penelitian}

Subjek penelitian yang dipilih dapat dikelompokan menjadi Sekolah Dasar (SD/MI), Sekolah Menengah Pertama (SMP/MTs), Sekolah Menengah Atas (SMA/MA), dan Sekolah Luar Biasa (SLB)

Tabel 1. Subjek Penelitian Akhir Mahasiswa PS. Pendidikan Fisika

\begin{tabular}{llc}
\hline No & \multicolumn{1}{c}{ Sekolah } & Jumlah \\
\hline 1 & SD/MI & 4 \\
2 & SMP/MT & 180 \\
3 & SMA/MA & 43 \\
4 & SMK & 6 \\
5 & SLB & 0 \\
6 & Perg. Tinggi & 1 \\
\hline \multicolumn{2}{r}{ Total } \\
\hline
\end{tabular}

Tabel 1. menunjukan kecendrungan mahasiswa Program Studi Pendidikan Fisika meneliti di SMP/MTs $(76,92 \%)$, dan pada enam tahun terakhir tidak ada melakuan penelitian di Sekolah Luar Biasa (SLB). Berdasarkan hasil Focus Group Discussion (FGD) terungkap bahwa pemilihan subjek penelitian didasarkan pada tempat mahasiswa tersebut melakukan PPL dan alasan keduanya karena materi pelajaran di SMP/MTs, lebih mudah. Hal tersebut yang menyebabkan sebagian besar mahasiswa melakukan penelitian di SMP/MTs. Padahal khusunya di SLB, perlu mendapatkan sentuhan penelitian yang berorientasi pada media pembelajaran berbasis video atau media pembelajaran yang memvisualisasikan, sehingga membantu anak-anak berkebutuhan khusus. Hal ini membuka peluang karena di NTB ada Sekolah Berkebutuhan Khusus atau SLB.

\section{Materi Pelajaran/Pokok Bahasan}

Penelitian mahasiswa Program Studi Pendidikan Fisika ada kecendrungan memusat pada pokok bahasan atau materi pelajaran tertentu dan belum ada pemerataan pada pokok bahasan yang lain. Fakta ini dapat dilihat dari sebaran pokok bahasan/materi pelajaran yang menjadi fokus penelitian mahasiswa seperti pada Gambar 1.

Pada Gambar 1. terlihat bahwa belum tersebarnya pokok bahasan atau materi fisika yang menjadi fokus penelitian mahasiswa PS. Pendidikan Fisika selama enam tahun terakhir, materi fisika seperti kemagnetan, kelistrikan, tata surya, dan fisika modern masih jarang diteliti oleh mahasiswa. Materi pelajaran yang paling banyak digunakan oleh mahasiswa adalah materi kalor dengan prosesntase $28 \%$. Sedangkan maksud dari pokok bahasan /materi lainnya adalah fokus penelitian yang bukan pada salah satu materi fisik misalnya: ketersediaan bahan ajar, laboratorium, dan jenis alat evaluasi.

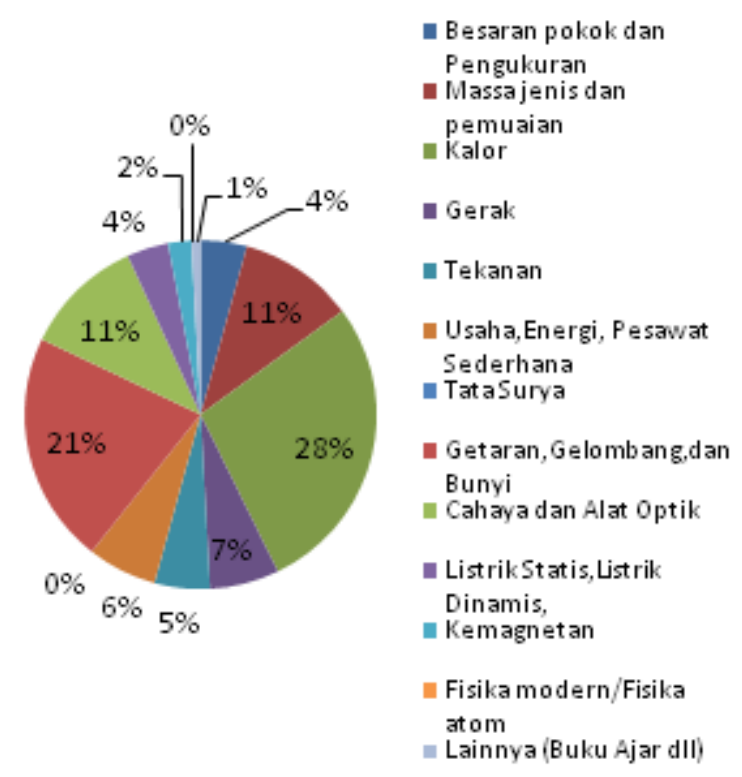

Gambar 1. Gambar Grafik Prosentase Materi Pelajaran yang Paling Banyak Diteliti Mahasiswa dari Tahun 2009 sampai 2014

Penelitian materi fisika seperti kemagnetan, kelistrikan, tata surya, dan fisika modern masih jarang diteliti oleh mahasiswa. Hal ini disebabkan karena materi tersebut berada di kelas IX (SMP/SMPTs) dan di kelas XII (SMA/MA), dimana kelas - kelas tersebut tidak boleh dijadikan objek penelitian karena kelas - kelas tersebut 
difokuskan untuk menghadapi ujian nasional, sehingga pihak sekolah tidak mengijinkannya

\section{Metode/Jenis Penelitian}

Jenis Penelitian atau metode penelitian yang digunakan mahasiswa PS. Pendidikan Fisika dapat dilihat pada Tabel 2 berikut.

Tabel 2. Metode/Jenis Penelitian Mahasiswa Program Studi Pendidikan Fisika

\begin{tabular}{llc}
\hline No & Metode/Jenis Penelitian & Jumlah \\
\hline 1 & PTK & 43 \\
2 & Eksperimen & 175 \\
3 & Survey & 4 \\
4 & Studi kasus/Expose Facto) & 0 \\
5 & Pengembangan (R \& D) & 8 \\
6 & Korelasional & 4 \\
\hline \multicolumn{2}{r}{ Total } & 234 \\
\hline
\end{tabular}

Berdasarkan data di atas menunjukan jenis penelitian eksperimen didominasi dilakukan paling banyak oleh mahasiswa PS. Pendidikan Fisika selama kurun waktu dari tahun 2009 sampai 2014, dan disusul dengan jenis penelitian PTK. Sedangkan penelitian survey jarang dilakukan dan penelitian jenis studi kasus bahkan sama sekali tidak ada.

\section{Tema/Isu-Isu Penelitian Pendidikan}

Tema atau isu-isu penelitian ini dikelompokan menjadi 2 diantaranya: tema pokok/utama dan tema sekunder. Berdasarkan data yang diperoleh tema inti atau isu utama penelitian dalam kurun waktu 2009 sampai 2014 didominasi penelitian tentang model pembelajaran dengan jumlah 75 judul penelitian (32\%) dan metode pembelajaran dengan jumlah 38 judul $(16 \%)$. Kecendrungan atau tren penelitian pendidikan sains khususnya pendidikan fisika selalu mengalami perubahan dari waktu ke waktu. Perubahan yang terjadi mengikuti fenomena perubahan yang terjadi di lapangan. Menurut White (1997) dalam [3] perubahan penelitian cenderung memusat pada metode penelitian dan bidang kajiannya. Pemilihan implementasi model pembelajaran didasarkan karena model pengajaran adalah cetak biru untuk mengajar, tetapi model itu tidak bisa mendikte" segala tindakan yang dilakukan oleh guru [9]. Prospek ke depan selain mengimplementasi model pembelajaran, penelitian pengembangan dalam skala kecil juga perlu direkomendasikan ke siswa, karena pada hakekatnya penelitian pengembangan ini, akan menghasilkan hal atau suatu produk yang baru. Sedangkan tema isu-isu skunder penelitian trend masing - masing tahun dapat dilihat pada beberapa gambar grafik di bawah ini. Tema sekunder merupakan produk atau hasil dari tema pokok/inti. Sedangkan tema isu-isu skunder penelitian trend masing - masing tahun dapat dilihat pada beberapa gambar grafik di bawah ini.
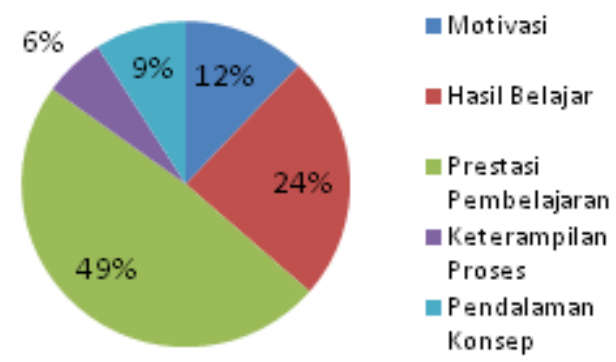

Gambar 2. Grafik Isu-isu Skunder Penelitian yang Didominasi Pada Tahun 2009
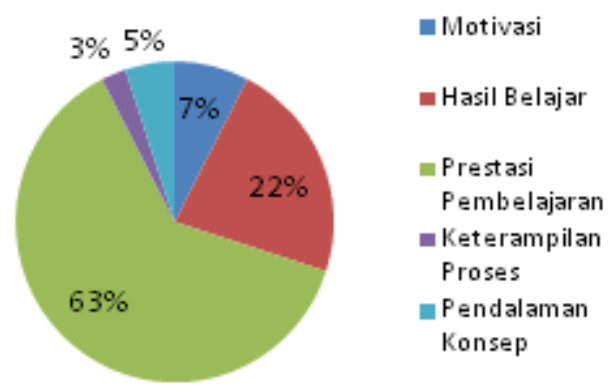

Gambar 3. Grafik Isu-isu Skunder Penelitian yang Didominasi Pada Tahun 2010

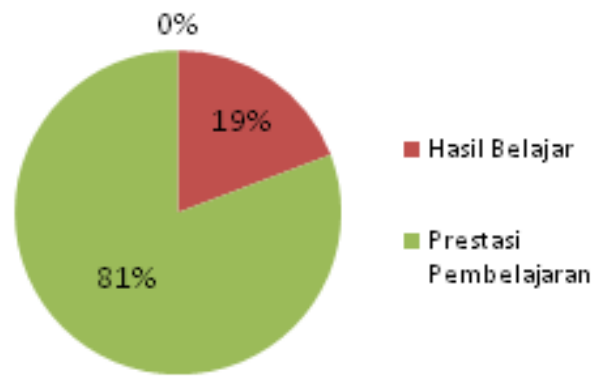

Gambar 4. Grafik Isu-isu Skunder Penelitian yang Didominasi Pada Tahun 2011

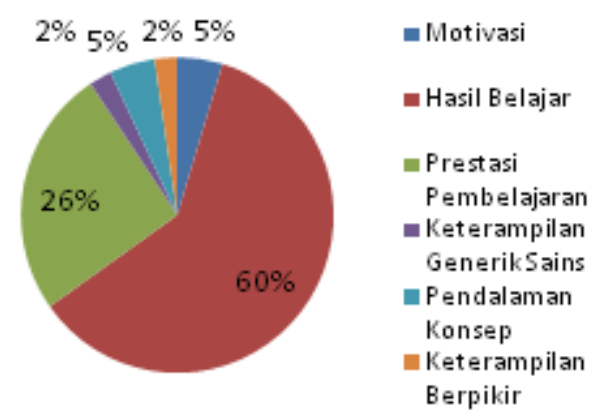

Gambar 5. Gambar Grafik Isu-isu Skunder Penelitian yang Didominasi Pada Tahun 2012 

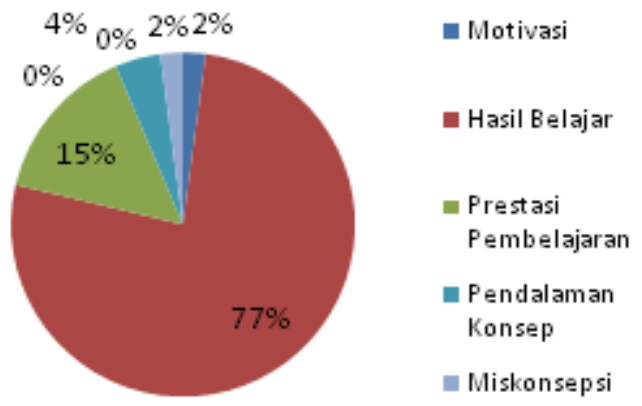

Gambar 6. Gambar Grafik Isu-isu Skunder Penelitian yang Didominasi Pada Tahun 2013
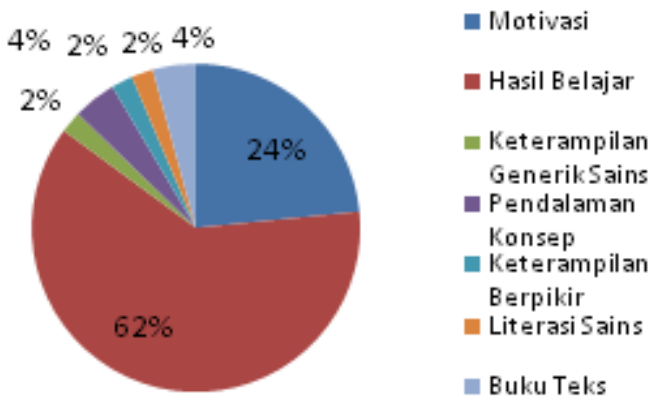

Gambar 7. Gambar Grafik Isu-isu Skunder Penelitian yang Didominasi Pada Tahun 2014

Sedangkan tema isu-isu skunder penelitian dari tahun 2009 sampai tahun 2014, isu-isu skunder penelitian memiliki trend yang berbeda - beda, Kemudian kalau diakumulasi selama 6 tahun isu - isu skunder penelitian mahasiswa PS.Pendidikan Fisika adalah tentang hasil belajar dan prestasi belajar. Seiring dengan implementasi kurikulum 2013 untuk mengembangkan kemampuan berpikir siswa dan menumbuhkan sikap keingin tahuan siswa, maka variable penelitian yang dipilih siswa diarahkan pada keterampilan berpikir, pendalaman konsep, gaya kognitif,life skill dan sikap ilmiah. Seperti yang disimpulkan beberapa ahli Macpherson dan Stanovich (2007) dalam [9] mengungkapkan bahwa manusia tidak memiliki kecendrungan alamiah untuk berpikir kritis dan orang yang memiliki motivasi berprestasi tinggi pun sering berpikir sama tidak kritisnya ketimbang mereka yang memiliki motivasi rendah. Hal ini menegaskan kemampuan berpikir kritis tidak dibawa sejak lahir, melainkan dapat dikembangkan dalam proses pembelajaran dan proses pembelajaran mendorong siswa berpikir kritis sangatlah perlu, karena kemampuan berpikir siswa dapat diubah dengan memberikan pembelajaran berpikir pada siswa.

\section{KESIMPULAN DAN SARAN}

Berdasarkan analisis data penelitian dan identifikasi terhadap hasil penelitian mahasiswa maka dapat disimpulkan bahwa: (1) Sebagian besar subjek penelitian mahasiswa PS. Pendidikan Fisika adalah SMP/SMTs dan jenis penelitiannya adalah penelitian eksperimen; (2) Isu isu penelitian pendidikan yang banyak diteliti oleh mahasiawa PS. Pendidikan Fisika adalah model pembelajaran dan metode pembelajaran, dan 3) Isu-isu pendidikan yang masing memungkinkan diteliti lebih lanjut adalah keadaan lab, gaya kognitif, life skills, keterampilan berpikir, pendalaman konsep, sikap imiah serta penelitian - penelitian yang sifatnya research dan develovment (pengembangan).

Berkaitan dengan penelitian ini, disarankan PS. Pendidikan MIPA FKIP Universitas Mataram sebaiknya mengarahkan penelitian-penelitian dalam jenis penelitian pengembangan dan variavel skundernya bukan saja hasil dan prestasi belajar, tetapi lebih diarahkan ke keterampilan berpikir, pendalaman konsep, sikap ilmiah, dan pengembangan media.

\section{DAFTAR PUSTAKA}

[1] Tim. 2011. Borang Akreditasi Program Studi Pendidikan Fisika. FKIP Universitas Mataram.

[2] Pedoman Penyelenggaraan Pendidikan FKIP Universitas Mataram, tahun akademik 2009/2010. Mataram

[3] Pujianto \& Suyoso. 2011. Analisis Kecendrungan dan Tren Penelitian Pada Mahasiswa Pendidikan Fisika Sebagai Revitalisasi Bidang Keahlian Penunjang Akreditasi: Studi Kasus Prodi Pendidikan Fisika FMIPA UNY. Prosiding Seminar Nasional Sains 2011.

[4] Kerlinger, F. N. 1986. Asas-asas Penelitian Behavioral. Terjemahan Landung R. Simatupang. 1990. Yogyakarta: Gajah Mada University Press.

[5] Tuckman, Bruce W. 1972. Conducting Educational Research. New York: Harcourt Brace Javonovich, Inc.

[6] Rahayu, S. 2012. Penelitian Pendidikan Kimia: Tren Global. Prosiding Seminar Nasional Kimia Unesa 2012. 25 Pebruari 2012. Surabaya.A2-A11

[7] Suparno, P. 2007. Metodologi Pembelajaran Fisika. Yogyakarta. Penerbit Universitas Sanata Dharma.

[8] Siswanto, I. \& Sampurno, Y. G. Faktor - Faktor Penghambat Penyelesaian Tugas Akhir Skripsi Mahasiswa Pendidikan Teknik Otomotif FT UNY.

[9] Eggen, P. dan Kauchak, D. 2012. Strategi dan Model Pembelajaran : Mengajarkan Konten dan Keterampilan Berpikir. Terjemahan Satrio Wahono. Jakarta. Penerbit PT Indeks. 